\title{
Regulation of Growth and Flowering by Plant Growth Regulators in African Marigold (Tagetes erecta L.) cv. Lemon Yellow
}

\author{
Arti Arha ${ }^{1}$, Paramveer Singh ${ }^{2 *}$ and L.R. Verma $^{3}$ \\ ${ }^{1}$ Department of Horticulture, RCA, MPUAT, Udaipur \\ ${ }^{2}$ Department of Horticulture (Veg. \& Flori.), BAU, Sabour \\ ${ }^{3}$ Department of Horticulture, C. P. College of Agriculture, SDAU, Sardarkrushinagar, India \\ *Corresponding author
}

\begin{abstract}
A B S T R A C T
Keywords

African marigold, Growth, Flowering,

Regulation, $\mathrm{GA}_{3}$, Ethrel, MH

Article Info

Accepted:

15 July 2019

Available Online:

10 August 2019

The investigation was carried out at Experimental Farm, Department of Horticulture, Chimanbhai Patel College of Agriculture, Sardarkrushinagar Dantiwada Agricultural University, Sardarkrushinagar (Gujarat). The experiment was aimed to determine the best plant growth regulator (s) for regulation of growth and flowering as well as to standardize the optimum concentration of these plant growth regulators for quality flower production of African marigold cv. Lemon yellow. The experiment was laid out in randomized block design with 10 treatments and replicated four times. Plants were planted on $30 \times 30 \mathrm{~cm}$ spacing and treated with three different plant growth regulators with different concentrations viz. $\mathrm{GA}_{3}(100 \mathrm{ppm}, 150 \mathrm{ppm}$ and $200 \mathrm{ppm})$, Ethrel (250 ppm, $500 \mathrm{ppm}$ and $750 \mathrm{ppm})$ and $\mathrm{MH}(250 \mathrm{ppm}, 500 \mathrm{ppm}$ and $750 \mathrm{ppm}$ ) along with control (water spray). The results revealed that the $\mathrm{GA}_{3}$ was the most potential growth regulator for producing higher yield with quality flowers and recorded earlier flowering. Ethrel $250 \mathrm{ppm}$ was also found to be effective for getting higher flower yield.
\end{abstract}

\section{Introduction}

Marigold is the most important commercial loose flower crop of India. It belongs to the plant family Compositae (Asteraceae). Marigold is grown in almost all states of India except the hilly temperate region. The major African Marigold growing states in India are Karnataka, Tamil Naidu, Andhra Pradesh, West Bengal and Maharashtra (Kameswari et al., 2011). The petals of African Marigold is a source of carotenoids especially lutein which is used as a natural pigment for textile colouration, colouring agent for food in confectionaries and an additive in poultry feed to intensify the yellow colouration in egg yolk (Kameswari et al., 2011). In India, marigold occupied an area of 66.13 thousand hectare with 603.16 thousand metric ton production during 2015-16 (Anonymous, 2017). African marigold is a predominant species cultivated extensively for commercial 
loose flower production due to its free flowering habit with long duration of blooming period, wider adaptability, higher ability to stand transportation shock and a wide array of colour of flower ranging from lemon yellow to orange red with moderate to high post-harvest life period.

The use of plant growth regulators to increases the productivity of horticultural crops is not a new one. Several plant growth regulators are used in different kinds of horticultural crops to induce more number of female flowers, sex expression in desired direction, flowering in flower crops. The marigold cultivation is rapidly expanding and the crop is very popular among the flower growers. It needs to be very essential to induce early flowering as well as to increase the productivity by alteration of growth, plant physiological and metabolic processes. Though application of plant growth regulators to improve the production of marigold is tried by some workers but the effort was not consolidated and the information related to these is very meagre. Considering all those facts in view here an attempt has been made to study the effect of three plant growth regulators namely Gibberellic acid $\left(\mathrm{GA}_{3}\right)$, Ethrel and Maleic hydrazide (MH).

\section{Materials and Methods}

Field experiment was conducted on African marigold (Tagetes erecta L.) cv. Lemon yellow at Experimental Farm, Department of Horticulture, Chimanbhai Patel College of Agriculture, Sardarkrushinagar Dantiwada Agricultural University, Sardarkrushinagar (Gujarat). The soil of experimental farm was medium loamy texture having organic carbon $0.23 \%$, available nitrogen $128 \mathrm{~kg} \mathrm{ha}^{-1}$, available phosphorus $37 \mathrm{~kg} \mathrm{ha}^{-1}$ and available potassium $218 \mathrm{~kg} \mathrm{ha}^{-1}$ and soil $\mathrm{pH}$ 7.83. The experiment was laid out in randomized block design with 10 treatments and replicated four times all the treatment. Immediately after transplanting of seedlings a light irrigation was given for better establishment of the seedlings. Plants were planted on $30 \times 30 \mathrm{~cm}$ spacing. Recommended dose of NPK (150: 50: $50 \mathrm{~kg} \mathrm{ha}^{-1}$ ) and other inputs were applied at appropriate time. The treatments comprising of three doses each of $\mathrm{GA}_{3} @ 100$ ppm ( $\left.\mathrm{T}_{1}\right), \mathrm{GA}_{3} @ 150$ ppm $\left(\mathrm{T}_{2}\right), \mathrm{GA}_{3} @ 200$ ppm $\left(\mathrm{T}_{3}\right)$, Ethrel @ 250 ppm $\left(\mathrm{T}_{4}\right)$, Ethrel @ 500 ppm $\left(\mathrm{T}_{5}\right)$, Ethrel @ 750 ppm $\left(\mathrm{T}_{6}\right), \mathrm{MH}$ @ $250 \mathrm{ppm}\left(\mathrm{T}_{7}\right), \mathrm{MH} @ 500 \mathrm{ppm}\left(\mathrm{T}_{8}\right), \mathrm{MH}$ @ $750 \mathrm{ppm}\left(\mathrm{T}_{9}\right)$ along with water spray (control i.e. $\mathrm{T}_{10}$ ). Foliar application of each treatment was given twice, first spray at 15 days after transplanting and second at 15 days after first spray. Both the surfaces of leaves and apical meristem were fully moistened. Different growth and flowering attributes were recorded to know significant effect of different plant growth regulators and their concentrations on African marigold $\mathrm{cv}$. Lemon yellow. Data recorded from five tagged plants in all treatments and each replication. Recorded data were analysed and presented in Table 1.

\section{Results and Discussion}

\section{Effect of plant growth regulators on vegetative growth parameters}

Maximum plant height was recorded in treatment $\mathrm{T}_{3}$ i.e. $\mathrm{GA}_{3}$ at $200 \mathrm{ppm}(59.60 \mathrm{~cm})$ as compared to all treatments. Minimum plant height was found in plants sprayed with 750 ppm MH $(38.91 \mathrm{~cm})$. Maximum number of branches were recorded in plants sprayed with $200 \mathrm{ppm} \mathrm{GA}_{3}$ (18.90) and minimum of that recorded from plants treated with $750 \mathrm{ppm}$ MH (7.95). The mechanism involved in primitive effect of gibberellins on growth may be due to increase auxin level of tissue or by enhanced conversion of tryptophan to IAA which caused cell division and cell elongation (Kuraishi and Muir, 1964). Increase in plant 
height as a consequence of $\mathrm{GA}_{3}$ treatments has also been reported by Pandya (2000) in marigold. Application of $\mathrm{MH}$ reduced plant height, which might be due to the fact that it lowers the auxin content and acts antagonistically to auxin, and thus, completely suppresses the apical dominance by inhibiting the cell division on the apical meristem (Crafts et al., 1950). Increase in number of branches progressively with the increase in concentrations of $\mathrm{GA}_{3}$ could be attributed to increase in photosynthesis and respiration with the enhanced carbohydrate fixation in $\mathrm{GA}_{3}$ treated plants.

\section{Effect of plant growth regulators on flowering parameters}

All the attributes were influenced significantly due to various plant growth regulators (Table-). Significant early initiation of flowering was observed in plants treated with $\mathrm{GA}_{3}$ at $200 \mathrm{ppm}$ (32.90 days) as compared to control (45.15 days) after transplanting. Whereas, significant delay in flowering was recorded in plants treated with MH @ 750 ppm (60.85 days) as compared to control. This is because gibberellins are quite effective in reducing juvenile period of plants. At the termination of juvenile phase, the shoot apical meristem is converted to flower primordia instead of producing leaves and branches (Krishnamoorthy, 1975). Increased photosynthesis and respiration with enhanced $\mathrm{CO}_{2}$ fixation in the treated plants was also associated with early flowering. Similar results were also reported by Dahiya and Rana (2001).

Significantly maximum flower diameter was observed in plants treated with $\mathrm{GA}_{3}$ @ 200 ppm $(7.5 \mathrm{~cm})$ and minimum flower diameter $(5.1 \mathrm{~cm})$ in plants treated with $\mathrm{MH} @ 750$ ppm. $\mathrm{GA}_{3}$ caused increase in flower diameter with the increasing concentrations. Whereas, higher concentration of Ethrel and all the concentration of $\mathrm{MH}$ reduced flower diameter as compared to control. The increment in flower diameter might be due to enhanced cell division and cell enlargement, promotion of protein synthesis coupled with higher dry matter of apical dominance (Dalai et al., 2009). Similar findings were also reported by Tyagi and Kumar (2006).

\section{Effect of plant growth regulators on flower yield parameters}

The maximum numbers of flowers per plant (36.25) were recorded in plants sprayed with $\mathrm{GA}_{3} @ 200$ ppm as compared to other treatments. Higher number of flowers per plant might be due to the production of more laterals at early stage of growth which had sufficient time to accumulate carbohydrate for proper flower bud differentiation due to enhanced reproductive efficiency and photosynthesis restrictive plant type. Significantly most impressive flower yield per plant $(82.62 \mathrm{~g})$ and per hectare $(9617.48 \mathrm{~kg})$ were recorded with plants sprayed with $\mathrm{GA}_{3}$ @ 200 ppm which was at par with $\mathrm{GA}_{3}$ @ 150 ppm and Ethrel @ 250 ppm. The influence of $\mathrm{GA}_{3}$ in increasing the flower yield was due to increased number of branches which led to increase in the number of flowers. After successful vegetative phase only, the plant could step into reproductive phase with better flower yield which was supported by increased weight of flowers. Increase in flower yield as a consequence of $\mathrm{GA}_{3}$ treatments has also been reported in African marigold (Sunitha et al., 2007).

\section{Effect of plant growth regulators on Vase life of flowers}

$\mathrm{GA}_{3} @ 200$ ppm showed its supremacy by enhancing the vase life of flowers (12.75 days) followed by MH 750 ppm (12.50 days). $\mathrm{GA}_{3}$ reduces the water loss and has antisenescence property leading to enhanced vase life. Similar results were found in marigold (Ramdevputra et al., 2009). 
Table.1 Effect of plant growth regulators on growth, flowering, yield and vase life of African marigold cv. Lemon yellow

\begin{tabular}{|c|c|c|c|c|c|c|c|c|}
\hline Treatments & $\begin{array}{c}\text { Plant } \\
\text { height } \\
(\mathrm{cm})\end{array}$ & $\begin{array}{c}\text { No. of } \\
\text { branches/ } \\
\text { plant }\end{array}$ & $\begin{array}{c}\text { First } \\
\text { flowering } \\
\text { (DAT) }\end{array}$ & $\begin{array}{c}\text { Flower } \\
\text { size } \\
(\mathrm{cm})\end{array}$ & $\begin{array}{c}\text { No. of } \\
\text { flowers/ } \\
\text { plant }\end{array}$ & $\begin{array}{c}\text { Flowers } \\
\text { yield } \\
\text { (g/plant) }\end{array}$ & $\begin{array}{c}\text { Flower } \\
\text { yield } \\
(\mathbf{k g} / \mathrm{ha})\end{array}$ & $\begin{array}{c}\text { Vase } \\
\text { life } \\
\text { (days) }\end{array}$ \\
\hline $\begin{array}{l}\mathrm{T}_{1}-\mathrm{GA}_{3} 100 \\
\mathrm{ppm}\end{array}$ & 52.46 & 14.65 & 38.45 & 6.3 & 30.15 & 60.81 & 7164.91 & 11.50 \\
\hline $\begin{array}{l}T_{2}-G_{A_{3}} 150 \\
\text { ppm }\end{array}$ & 54.50 & 15.45 & 36.15 & 6.8 & 34.60 & 73.12 & 8614.86 & 12.25 \\
\hline $\begin{array}{l}T_{3}-G_{4} 200 \\
\text { ppm }\end{array}$ & 59.60 & 18.90 & 32.90 & 7.5 & 36.25 & 82.62 & 9617.48 & 12.75 \\
\hline $\begin{array}{l}\mathrm{T}_{4} \text {-Ethrel } 250 \\
\text { ppm }\end{array}$ & 46.85 & 13.15 & 50.15 & 6.6 & 30.65 & 70.25 & 8344.92 & 9.25 \\
\hline $\begin{array}{l}T_{5} \text {-Ethrel } 500 \\
\text { ppm }\end{array}$ & 44.55 & 14.40 & 51.65 & 6.8 & 28.60 & 66.65 & 7828.18 & 9.00 \\
\hline $\begin{array}{l}T_{6} \text {-Ethrel } 750 \\
\text { ppm }\end{array}$ & 41.87 & 14.90 & 55.90 & 5.7 & 24.25 & 52.08 & 6231.70 & 8.25 \\
\hline $\begin{array}{l}\text { T }_{7}-\mathrm{MH} 250 \\
\text { ppm }\end{array}$ & 46.60 & 10.25 & 53.45 & 6.0 & 29.35 & 63.95 & 7550.53 & 11.00 \\
\hline $\begin{array}{l}\text { T }- \text {-MH } 500 \\
\text { ppm }\end{array}$ & 42.21 & 10.40 & 56.65 & 5.2 & 26.50 & 53.63 & 6385.95 & 12.00 \\
\hline $\begin{array}{l}\text { T9-MH } 750 \\
\text { ppm }\end{array}$ & 38.91 & 7.95 & 60.85 & 5.1 & 21.45 & 48.30 & 5792.08 & 12.50 \\
\hline$T_{10}$ - Control & 48.63 & 12.05 & 45.15 & 6.2 & 26.10 & 59.46 & 7018.37 & 9.50 \\
\hline S. Em. \pm & 1.08 & 0.62 & 0.56 & 0.12 & 0.58 & 4.96 & 527.63 & 0.53 \\
\hline C.D. at 5\% & 3.14 & 1.79 & 1.62 & 0.36 & 1.69 & 14.39 & 1531.14 & 1.53 \\
\hline
\end{tabular}

On scrutinizing the results, it can be concluded that $\mathrm{GA}_{3}$ was the most potential growth regulator for producing higher yield with quality flowers and also recorded earlier flowering. Ethrel 250 ppm was also found to be effective for getting higher flower yield per plant and flower yield per hectare.

\section{References}

Anonymous, 2017. Horticultural Statistics at a Glance, 2017. Horticulture Statistics Division, Department of Agriculture, Cooperation \& Farmers Welfare, Ministry of Agriculture \& Farmers Welfare, Government of India, pp: 481. 
Crafts, A.C., Durrler, H.B. and Day, B.E., 1950. Response of several crop plants and weeds to maleic hydrazide. Hilgardia, 20: 57-80.

Dahiya, D. S. and Rana, G. S., 2001. Regulation of flowering in chrysanthemum as influenced by GA and shade house of different intensities. South Indian Horticulture, 49: 313- 314.

Dalai, S. R., Karale, G. D. and Morain, K. C., 2009. Effect of growth regulators on growth, yield and quality of chrysanthemum under net house conditions. Asian Journal of Horticulture, 4 (1): 161-163.

Kameswari P L, Girwani A, Kumar P N, Kumar G and Kumar R., 2011. In: Marigold. Directorate of Floricultural Research, I.C.A.R, New Delhi, India 126.

Krishnamoorthy, H.N., 1975. Gibberellin and plant growth. Halster Press, John Willey and Sons Inc. New York.

Kuraishi, S. and Muir, R.M., 1964. The mechanism of gibberellic action in the dwarf pea. Pl. Cell. Physiol. 5: 259.

Pandya, P., 200). Effect of PGRs on growth, yield and vase life of African marigold (Tagetes erecta) v. "Lemon yellow". Unpublished M. Sc. (Agri.) thesis submitted to G.A.U., Anand.

Ramdevputra, M. V., Deshmukh, H. N., Butani, A. M., Savaliya, J. J., Pansuriya, A. G. and Kanzaria, D. R., 2009. Effect of different gibberllic acid $\left(\mathrm{GA}_{3}\right)$ concentrations on growth, flowering and yield of African marigold. The Asian Journal of Horticulture, 4 (1):8285.

Sunitha, H. M., Hanje R., Vyakaranahal, B. S. and Bablad H. B., 2007. Effect of pinching and growth regulators on plant growth, flowering and seed yield in African marigold (Tagetes erecta L.). Journal of Ornamental Horticulture, 10 (2): 91-95.

Tyagi, A. K. and Kumar V., 2006. Effect of gibbrellic acid and vermi compost on vegetative growth and flowering in African marigold (Tagetes erecta Linn.). Journal of Ornamental Horticulture, 9 (2): 150-151.

\section{How to cite this article:}

Arti Arha, Paramveer Singh and Verma, L.R. 2019. Regulation of Growth and Flowering by Plant Growth Regulators in African Marigold (Tagetes erecta L.) cv. Lemon Yellow. Int.J.Curr.Microbiol.App.Sci. 8(08): 1704-1708. doi: https://doi.org/10.20546/ijcmas.2019.808.201 